\title{
The cover of Herbs' first \\ Pacific reggae album: Perusing the paratext
}

Elizabeth Turner

Keywords: \#Herbs \#What's Be Happen? \#Pacific reggae \#album cover \#paratext \#context

The cover of Herbs' award-winning EP What's Be Happen? is dominated by an image of the final day of the Bastion Point occupation in Ōrākei, Auckland on 25 May, 1978. Released in 1981, the album has been recognised in a number of music industry awards for its important contribution to cultural life in Aotearoa New Zealand, and for the musician's brave political stance in a period of activism that achieved significant social change. This article presents an analysis of the ways in which the record cover acts as a visual and textual introduction to the songs it encloses. Drawing on theorisations of features of paratext such as the title and images on a record sleeve as thresholding devices and as textual extensions of the records they enclose, the paper explores Herbs' album title, the typographic forms of the title and the band's name, and the use of colour, as well as the textual organisation of the songs on the two sides of the record. With reference to the social and political context at the time of the album's release, the article offers an interpretation of the identifications and values signified by these elements of the cover, as carriers of meaning. 


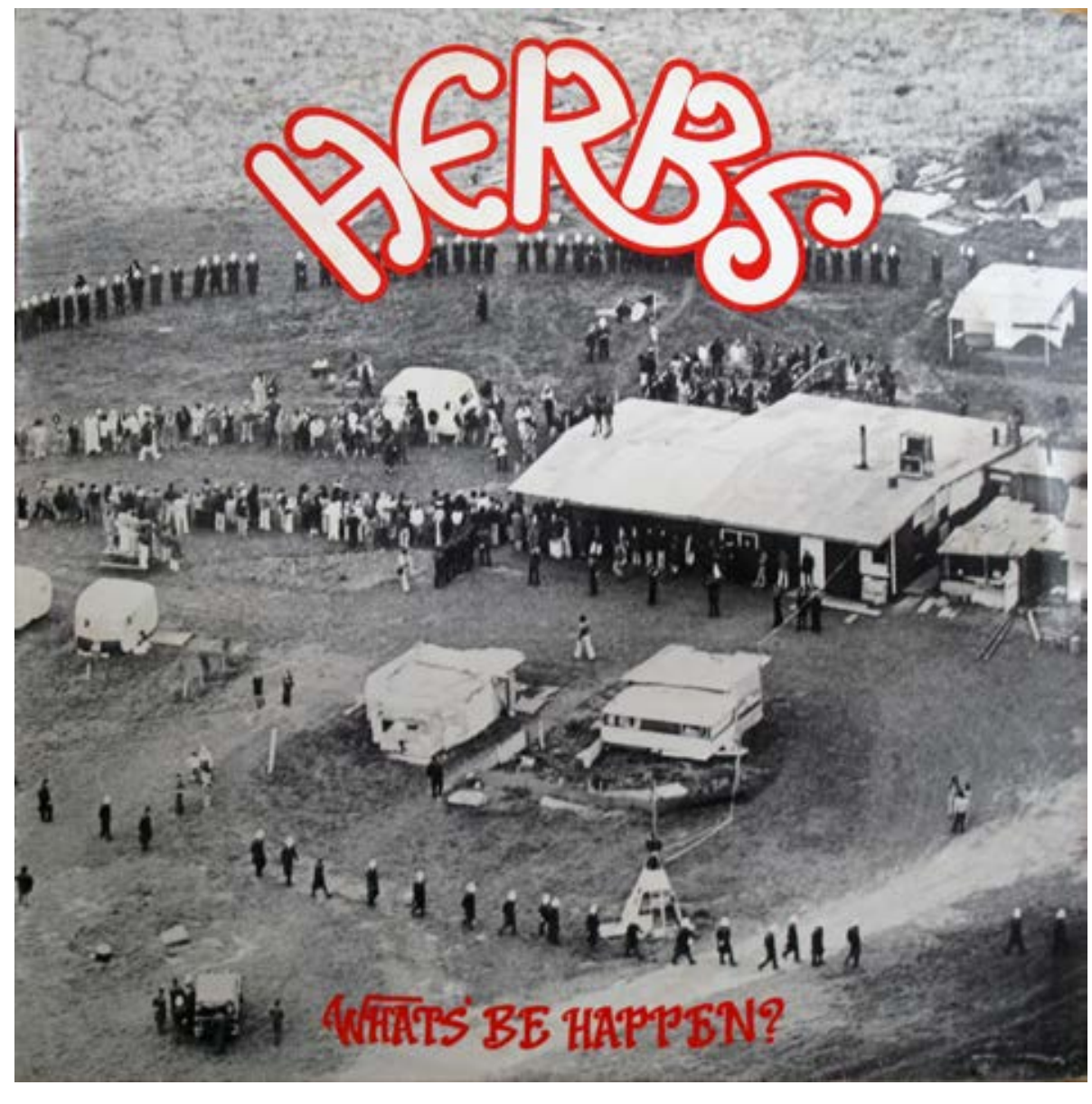

Figure 1: Front cover of Herbs' album What's Be Happen?

The front cover of Herbs' EP record What's Be Happen? is a photographic image of the final day of the Bastion Point occupation in Ōrākei, Auckland on 25 May, 1978. The black and white aerial photograph ${ }^{1}$ shows a moment during the contentious eviction of Māori land rights protesters after 507 days of occupation in an attempt to prevent the sale of traditional Māori land for luxury housing. In what has been described as a depiction of the clash between the mana of Māori and Pakeha authority ${ }^{2}$, the image shows part of a large circle of white-helmeted police officers surrounding the meeting house and a scattered handful of protestors' caravans. The police officers in the upper area of the circle stand in position with hands behind their backs, facing inwards. Other officers are seen filing into position in the lower segment of the photograph while protestors stand on either side of a pathway that leads away from the meeting house, which is positioned off centre in the composition. The name of the band is superimposed at centre top in white curved letters outlined in red, and the mini-album title in red is centred at the bottom. The symmetrically positioned lettering of the foregrounded name and title curves towards to centre of the photograph, echoing the circle of police officers. In enclosing the image and encircling the police circle, the curvature of the typography suggests an embrace, a signal of willingness to support and speak for those damaged by the events depicted in the image. Along with the question posed by the album title, the photograph signals and contextualises the political content of Herbs' songs as well as suggesting the orientation of the musicians in relation to that content. In 1981, at a time when Aotearoa New Zealand had no tradition of political bands, the choice of image was unequivocal as a statement of political stance. What's Be Happen? is the country's first Pacific reggae album, and its release by Warrior Records in 1981 is regarded as a turning point in the history of New Zealand popular music. Although it was not commercially successful in terms of sales, the album and the band have been formally recognized in a series of awards for their significant cultural and political influence in an important period of activism in Aotearoa New Zealand. The multi-ethnic mix of five Herbs musicians introduced an innovative and distinctive style of Pacific reggae ${ }^{3}$ which localised Jamaican roots reggae $^{4}$ and embodied the influence of Bob Marley on Māori and Pacific Islands musicians, activists and audiences in particular. The band was inducted into the Aotearoa New Zealand Music Hall of Fame at the Silver Scroll Awards in September 2012, and in April 2015 Herbs musicians,

Warrior Records founder Hugh Lynn, and the label and artist manager Will 'llolahia were presented with the Independent Music New Zealand (IMNZ) Classic Record award for What's Be Happen? at the Taite Music Prize event. In June the same year the band was again recognised when they won the Manukau Institute of Technology Lifetime Achievement Award at the Vodafone Pacific Music Awards in Auckland. That award was for What's Be Happen?, described at the ceremony as a ground breaking album of social commentary, and for Herbs' second album Light of the Pacific released in 1983. This paper focuses on an exploration and interpretation of the ways in which the peritext ${ }^{5}$ of the cover of Herbs' first record album, in its design and content, acts as a visual and textual introduction and an extension to Herbs' songs. In addition to the images on the album cover it discusses the album title, 
the typographic forms of the album title and the band's name, and the use of colourb; as well as the textual organisation of the songs on the two sides of the record.

In adopting the name of one of the four songs written by founding Herbs musician Toni Fonoti for the album title, Herbs chose a slang expression used by stylish Pacific Islands youth in Aotearoa New Zealand at the time the songs on the album were written. That song, What's Be Happen? is structured as a "hidden dialogue" , a probing soliloquy in which the singer narrator appears to hold a conversation with absent speakers. In a narrative structure shaped by the imagined utterances and experiences of invisible addressees, the song questions contradictions between the aspirations of Pacific Islands and Māori people for a better material life ${ }^{8}$ and the economically oppressive and miserable realities of life for many migrants in urban Aotearoa New Zealand:

Say you're alright brada, cause you got hire purchase No need to pay just slave and slave and slave...

What's be happen, when the children turn away

And why for you stay when nothing remains...?

Although Toni Fonoti was not conscious of it at the time ${ }^{10}$ there appears to be an intertextual connection between the title of Herbs' album (and of their song by the same name) and the title of Marvin Gaye's influential album and single What's Going On, released in 1971". Gaye's politically charged album includes songs of protest that are a commentary on social suffering and injustice, urban decay, police brutality and conflict in the United States, from the generalised point of view of a soldier returning from the war in Vietnam. Herbs' apparent localisation of Gaye's title in the vernacular of young Pacific Islands people and the rhetorical device of juxtaposing the album title and the photograph of Bastion Point suggest the significant intertextual influence of Gaye's seminal album. As Herbs' bass player and songwriter Phil Toms, recalls, the decision to adopt the name of Toni Fonoti's song as the title of Herbs' album had been taken before the cover image was decided on. That choice was made after the band had completed recording, when the musicians went to Hugh Lynn's house to celebrate; the Bastion Point photograph was on the wall and it was Phil Toms who suggested including that image on the cover ${ }^{12}$.
The fact that there is no question mark in Gaye's title suggests an intentional framing of his album as a firm statement of social injustices. In contrast, Herbs' title, as a question, suggests an engagement with listeners in an interrogation of events, conflicts and experiences that formed the album's social and political context and are represented in the main image of the album cover and in the recorded songs that the cover encloses. The 1970s and early 1980s were a period of important change in the recent history of Aotearoa New Zealand. There were conflicts and campaigns over human rights, ethical values, and national identity, and over the kind of society people wanted in Aotearoa New Zealand ${ }^{13}$. These included protests against nuclear testing in the Pacific, campaigns against serious degradation of the environment and against the racist apartheid regime in South Africa, as well as campaigns for women's rights, gay rights and homosexual law reform ${ }^{14}$. People from the Pacific Islands were subjected between 1974 and 1976 to frightening race-based dawn raids by police with dogs, searching for people they suspected had stayed beyond the terms of their entry permits, the so-called over stayers. Pacific Island and Māori youths experienced police harassment and random police checks on Polynesian looking people on the streets of Auckland and were arrested for being "idle and disorderly"15. And many Pacific Islands and Māori people who had moved from the Islands and from rural areas to urban Aotearoa New Zealand suffered from the loss of homeland and island roots, from a sense of cultural dislocation and from economic and social hardships in suburbs with poor housing conditions. There were also significant struggles over the loss of traditional Māori land. These are not only represented in the image on the front cover but also linked in the album track "One Brotherhood" to the racism of apartheid, and to protests against the racially selected South African Springboks team's rugby tour of Aotearoa New Zealand which was to take place between July and September $1981^{16}$

The signalling of the social commentary constructed in Herbs album in the image and album title is augmented by the typography of the title (see Figure 1) in which the impression of an almost graffitilike social comment is reinforced by the uneven positioning of letters along a notional baseline (see the " $\mathrm{H}$ " in particular). At the same time, an upward curve of letters at the beginning and end of the title has the effect of partially enclosing the image, signifying the relationship between the photograph with its high visual modality and the title question. 
There is a similarity between the typography of the title and the design of the "Warrior Records" logo positioned on the right hand corner of the rear of the album cover (see Figure 2). Although the fonts differ slightly in terms of the size of the serifs (the projections that finish off the strokes of letters) the letters are similarly cursive but are not completely joined. In both texts there is slight elongation in the vertical axis and narrow spacing between letters. The form of the name "Warrior" can be understood as evoking a line of Māori warriors standing more or less to attention (the second stem of the " $A$ " slopes towards the first letter). Furthermore, the relatively "spiky" form of the letter " $W$ " in the company logo is suggestive of the taiaha, a wooden or bone fighting staff with a long-handle used by Māori warriors, while the final, ascending component of the "W" is heavy, and extends horizontally to enclose both words, connoting a protective palisade surrounding the "warrior" letters.

In a further connotation of Māori culture, the thick, curvilinea letters of the band's name bring to mind the hand crafted kowhaiwhai designs associated with Māori wood carving (evoked in the connection between the " $R$ " and the " $B$ " in particular), which is frequently characterised by interlocking curved shapes, and the stylised spiral koru' ${ }^{17}$. The Herbs' logo has been an enduring contribution to the band by bass player and graphic artist John Berkley. Berkley replaced the first bass player Dave Pou in Back Yard, the precursor to Herbs, but left the band in 1981 just before Herbs began to prepare to start recording, and his place was filled by Phil Toms. In Berkley's design, letter strokes end in ball-shaped terminals, with the exception of vertical ascenders, and these are particularly pronounced in the final " $\mathrm{S}$ ". These shapes are associated in Aotearoa New Zealand with the koru motif, the stylised spiral shape of an unfurling fern frond, a symbol of renewal that is ubiquitous in wood carving and other forms of Māori art. ${ }^{18}$ The same koru form is echoed in the question mark at the end of the album title, and on a smaller scale in stroke and serif terminals in the title.

The use of colour is also significant. The red and white in Herbs' name, red in the album title, black in the record company logo and the black and white images, can be interpreted as signifying Māori mana (symbolised by the colour red), Māori culture and the interests of Māori . These traditional colours feature strongly and have cultural significance in Māori woodcarving and other art forms, and they carry political meaning as the three colours of the Māori Tino Rangatiratanga (sovereignty) flag.

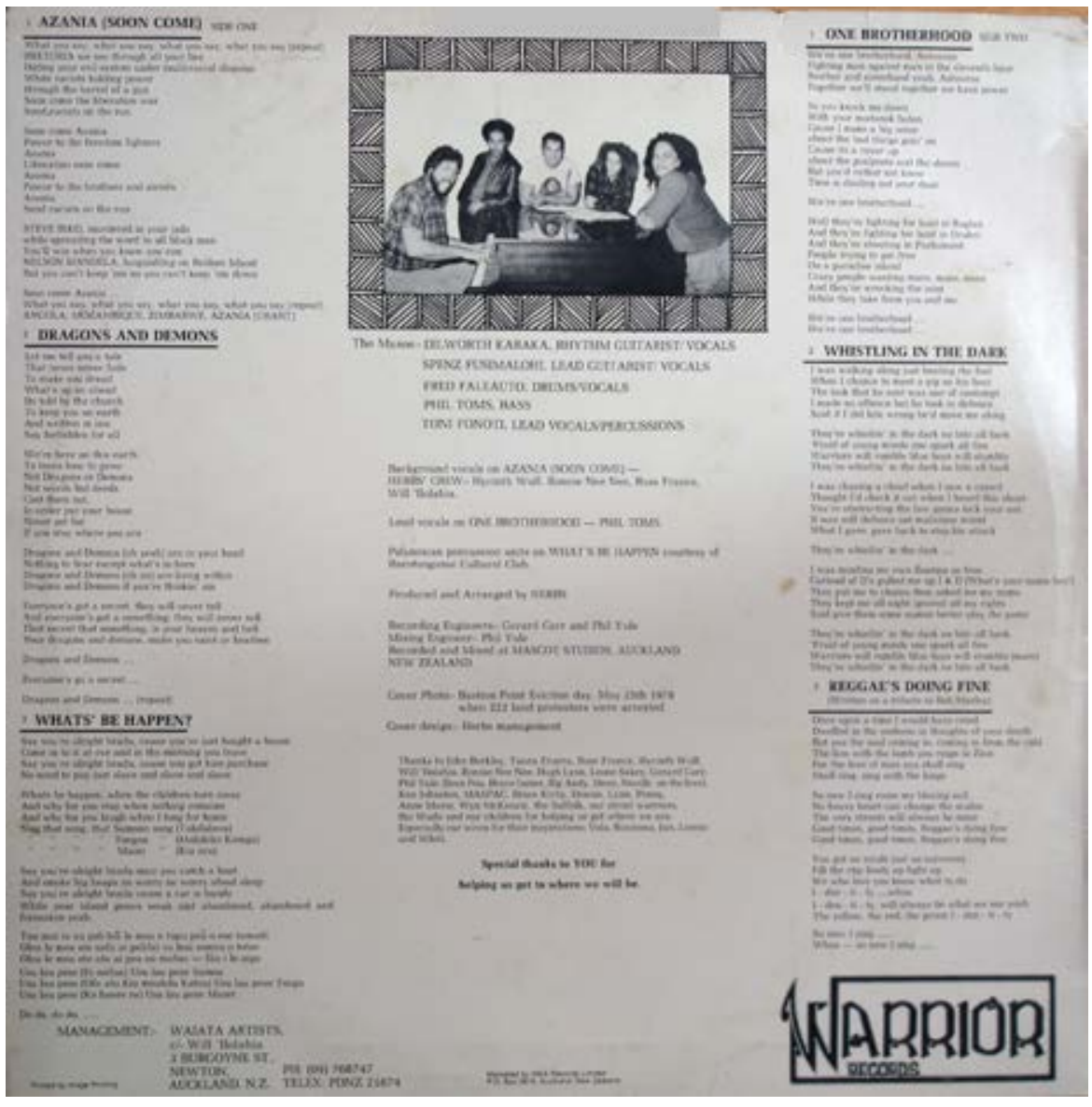

Figure 2: Rear cover of Herbs' album What's Be Happen?

There is a contrast between the allusions to Māori culture in the image and text on the front of the album cover and those created through the image on the rear of the sleeve, a much smaller black and white photograph (see Figures 2 and 3). The photograph of Herbs musicians is edged by a frame that in this context evokes Pasifika weaving patterns. In 1981 Herbs consisted of vocalist and song-writer Toni Fonoti of Samoan heritage, Tongan drummer Fred Faleauto and guitarist Spenser Fusimalohi, Māori rhythm guitar player Dilworth Karaka and European bassist and song-writer Phil Toms, and these musicians are posed around a piano, encircling it in a way that mirrors the curved positioning of the letters in the band's name. 


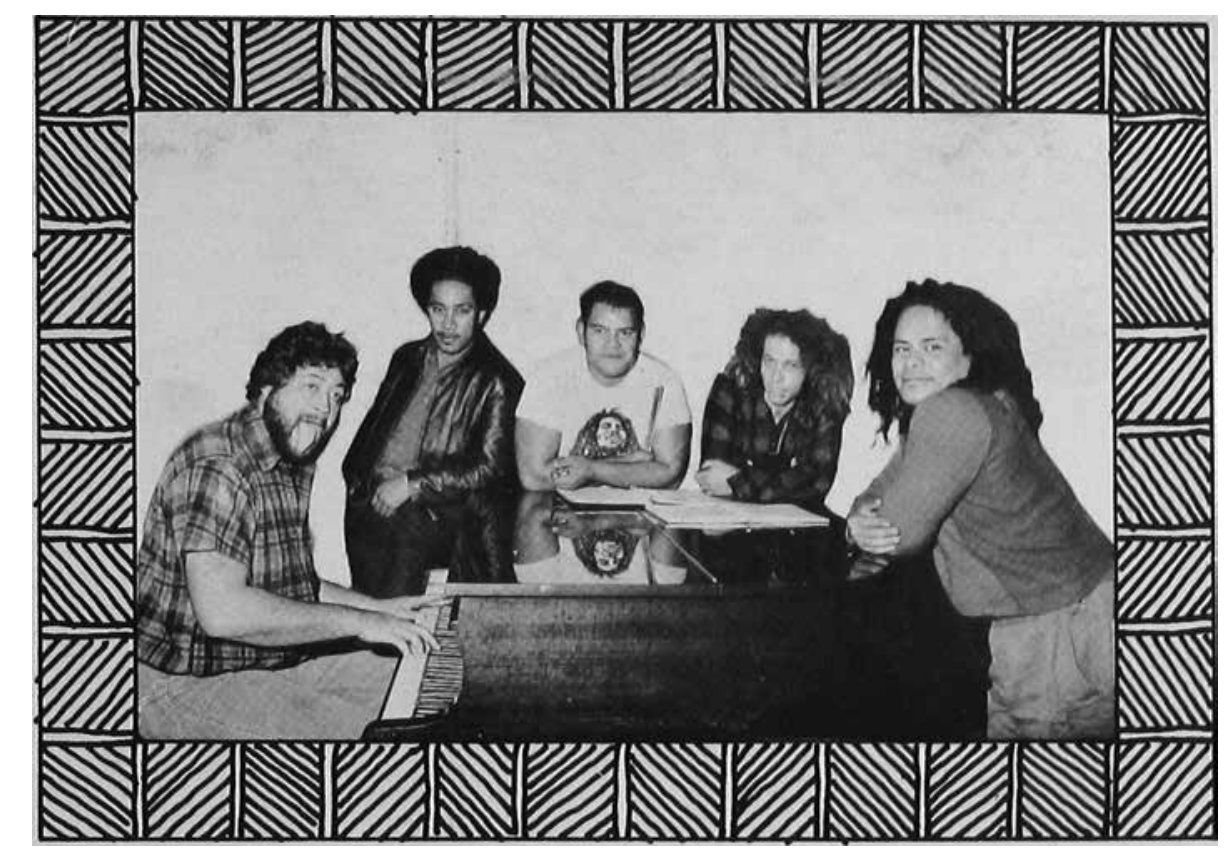

Figure 3: Image detail from rear cover of Herbs' album What's Be Happen?

The posture of the musicians is relaxed; their level gaze, juxtaposed with Dilworth Karaka's Māori facial expression, engages the viewer and the close shot serves to reduce social distance through the relative proximity of the figures to the camera. These combined effects create an impression of a brotherhood of different ethnic and cultural backgrounds united literally and metaphorically around music. The image suggests a representation of the kaupapa of unity that is reinforced by the title of the first track on Side Two, "One Brotherhood", and its lyrics: "We're one brotherhood... brotherhood and sisterhood yeah, Aotearoa"19. In contrast, the dominant image of Bastion Point on the front of the sleeve documents lived realities that contributed to the rupturing of the ideology of Māori and Pākehā living in harmony as one people en $^{20}$

The central section of the back of the album cover beneath the photograph of Herbs musicians is followed by a list of credits: to the musicians ("The Musos"), and their contributions; background vocalists on the track "Azania (Soon Come)"; The Rarotonganui Cultural Club for percussion segments in "What's Be Happen?"; recording and mixing engineers, Mascot (recording) Studios and Herb's management (for the cover design) and some 25 names, acknowledged with the words "thanks to...for helping us get where we are". These thanks are echoed in the text that follows in a parallel construction that reads: "Special thanks to YOU for helping us get to where we will be". The use of bold for these words, their centre alignment and the use of capital letters signal and emphasise a shift of focus from the musicians and all those who helped to produce the album, to the audience, to the significance of those who hear the music and see the album cover. At the same time the words signal a shift in focus from the past and present to the future. Like the image of the musicians above it, the message to "YOU" is an engagement with the reader. This direct address to the audience and the effect of reducing the social distance between the audience, the musicians and the team that produced the album suggests that the readers and listeners who hold the album and who hear the music, those "who listen and... understand" 1 are, and should be, part of a sisterhood and brotherhood committed to helping achieve a future free from racism, injustice and oppression.

Although changes in technological mediation involving digital files and the ability to buy single tracks off an album from an online store have changed the ways in which we listen to music ${ }^{22}$, as a vinyl EP and a physical artefact Herbs' album has two sides. It has to be turned over in order to listen to the songs on each side. The typical approach and custom in listening to a vinyl record album is to listen to Side One first, starting with the first track, to turn the record over on the turntable and listen to the songs on Side Two. The order of the tracks on each side of an album therefore has significance. In the case of Herbs' album, the organisation of the six songs and relationships between them are constructed sonically if the songs on the record are listened to in sequence. Some of these relationships are represented materially on the back of the record sleeve (see Figure 2 ) in the sequence of song titles listed for each side, and in the "carved-up shape of the lines [of the lyrics] on the page" ${ }^{23}$.

A symmetry is achieved between the two sides of the record in that each of the track lists begins with an overtly political track, includes a song that narrates experiences of Pacific Islands people, was well as another that involves the theme of spirituality. "Azania (Soon Come)", the first track on Side One, is musically and lyrically the most forceful of the six songs, with its strong, driving reggae beat, voices of additional vocalists that intensify the sound of the chorus and final chanting, as well as incorporated liberation slogans, and the strong assertion that racism will be overpowered in apartheid South 
Africa: that Azania - a South Africa freed from racist white-minority control - "(soon come)"24. Side Two begins with the explicitly political "One Brotherhood" in which the lyrics connect the violence of police treatment of protestors, social injustice, apartheid South Africa, and what Ranginui Walker describes as the struggle against oppressive and racist treatment made manifest in the ongoing loss of Māori land ${ }^{25}$. The spiritual theme of "Dragons and Demons" 26 on Side One is echoed in references to Rastafari spirituality in the tribute to Bob Marley and to reggae in the final acoustic track, "Reggae's Doing Fine" ${ }^{27}$, on Side Two. The commentary on hardships faced by migrants from the Pacific Islands in "What's Be Happen?" on the first side is counterbalanced by the narration of experiences of police harassment in "Whistling in the Dark" 28 on Side Two. The track lists thus introduce and document the organisation of the six tracks in which overtly political songs at the beginning of each side frame those that follow. In doing so these initia songs establish an explicitly political context in which the subsequent songs are heard and interpreted.

The recorded Pacific reggae songs that the cover encloses can be understood as an identification with the values and rhetorica functions associated with Jamaican roots reggae as message music, a genre that expresses the social realities of its practitioners and

functions as a "musical weapon" against oppression and injustice ${ }^{29}$. Similarly, as this exploration suggests, the allusion to Marvin Gaye's album title can be interpreted as a signal of the band's positioning in relation to African American soul music and the role of that music in addressing social injustice and conflicts.

The choice of image on the front cover, the use of colour and other visual components contribute to a form of positioning ${ }^{30}, a$ cultural and political statement of identity, and an identification and ethical alignment with the rights of those who struggled against racism and injustice. At the same time, the image of Herbs musicians on the back of the album cover implies the need for cultural unity in the face of these struggles, a unity grounded in reggae music. The dialogic relationship between the colour red in particular and the image on the front of the cover can be understood to signify the discourse of Māori mana and by implication the protest of Māori and others who campaigned against the ongoing erosion of Māori land ownership. Furthermore, references to the koru in the typography discussed here can be seen as signifying not only growth and renewal but also the resurgence of Māori political activism and self-assertion that emerged at the end of the $1970 s^{31}$ in what James Belich describes as a new form of Māori "decolonisation"32. In this context the choice of the main image is an explicit statement of political orientation in relation to the protests and occupation at Bastion Point and as this article has shown, like the title, acts as a thresholding device for the songs on the record itself.

\section{REFERENCES}

Bakhtin, Mikhail. Problems of Dostoevsky's Poetics. Translated by Caryl Emerson. Manchester, England: Manchester University Press, 1984.

- "Toward a Methodology for the Human Sciences." Translated by Vern W. McGee. In Speech Genres and Other Late Essays edinec by Caryl Emerson and Michael Holquist, 159-72. Austin, TX: University of Texas Press, 1986.

Barthes, Roland. Image/Music/Text. Translated by S. Heath. New York, NY: Noonday, 1977.

Belich, James. Paradise Reforged. Auckland, New Zealand: Penguin, 2001.

Cleveland, Al, Renaldo Benson, and Marvin Gaye. What's Going on [Recorded by Marvin Gaye]. On What's Going on [Vinyl Record]. Detroit, MI: Tamla Records, 197

Dix, John. Stranded in Paradise: New Zealand Rock and Roll - 1955 to the Modern Era. Wellington, New Zealand: Penguin, 2005.

Dunn, Michael. New Zealand Sculpture: A History. Auckland, New Zealand: Auckland University Press, 2002.

Eagleton, Terry. How to Read a Poem. Oxford, England: Blackwell, 2007.

Fonoti, Toni. Dragons and Demons [Recorded by Herbs]. On What's Be Happen? [Vinyl Record]. Auckland, New Zealand: Warrior Records, 1981c.

- Reggae's Doing Fine [Recorded by Herbs] On What's Be Happen? [Vinyl Record]. Auckland New Zealand: Warrior Records/WEA, 1981b.
-Whistling in the Dark [Recorded by Herbs] On What's Be Happen? [Vinyl Record]. Auckland New Zealand: Warrior Records/WEA, 1981a.

Fonoti, Toni What's Be Happen? [Recorded by Herbs]. On What's Be Happen? [Vinyl Record]. Auckland: Warrior Records/WEA, 1981d.

France, Ross. Azania [Recorded by Herbs]. On What's Be Happen? [Vinyl Record]. Auckland, New Zealand: Warrior Records, 1981.

Genette, Gerard. Paratexts: Thresholds of Interpretation. Cambridge, England: Cambridge University Press, 1997.

Hall, Stuart. "Cultural Identity and Diaspora." In Identity: Community, Culture, Difference, edited by J. Rutherford, 222-37. London, England: Lawrence and Wishart, 1990.

Hoar, Peter Morton. “Hearing the World: Audio Technologies and Listening in New Zealand, 1879-1939." The University of Auckland, 2012.

Hubbard, Anthony. "For a Good Cause." Sunday Star Times, August 29 2010, C4.

King, Michael. The Penguin History of New Zealand. Auckland, New Zealand: Penguin, 2003. Kress, Gunther R., and Theo van Leeuwen. Reading Images:The Grammar of Visual Design. London, England: Routledge, 1996.

Machin, David. Analysing Popular Music: Image, Sound, Text. London, England: Sage, 2010.

Morrison, Bruce "Bastion Point: The Untold Story (Tv Documentary)." New Zealand: Morrison Grieve and Moko Productions, 1999 
Swann, Cal. Language \& Typography. London, England: Lund Humphries, 1991.

Symes, Colin. Setting the Record Straight: A Material History of Classical Recording. Middletown, CT: Wesleyan University Press, 2004

Toms, Phil. One Brotherhood [Recorded by Herbs]. On What's Be Happen? [Vinyl Record]. Auckland, New Zealand: Warrior Records, 1981.

Turner, Elizabeth. “One Brotherhood in Aotearoo New Zealand: Protest, Resistance and Pacific Reggae." Music and Politics XII, no. 2, Summer 2018 (2018). doi:http://dx.doi.org/10.3998/ mp. 9460447.0012 .204

\section{END NOTES}

1 Although this photograph is not attributed, a similar aerial photograph from the New Zealand Herald archive was published on 30 May 2015 (see Suzanne McFadden, 2015 "Auckland's 175th anniversary: Season of discontent" at http://www.nzherald.co.nz/nz/ news/article.cfm?c_id=1\&objectid=11456874).

2 John Dix, Stranded in Paradise: New Zealand Rock and Roll - 1955 to the Modern Era (Wellington, New Zealand: Penguin, 2005).

3 With the exception of the final track on the album, which was recorded as a tribute immediately after the death of Bob Marley, and after the end of the main recording sessions, all of the songs on the album are reggae songs

4 See Thomas J. Weber, "Likkle but Talawah (Small but Mighty): Reggae Music, Globalization, and the Birth of a Social Movement (Phd Thesis)." Bowling Green State University, 2000. Weber defines roots reggae as the form popularised internationally by Bob Marley and others, featuring full instrumentation and harmonized vocals; it is now less frequently heard in Jamaica, where "dancehall" reggae form, with spoken vocals and computer-generated backing, predominates "Introduction", in lan Bidde pre Vanessa Knights (eds), Music, Nationa Identity and the Politics of Location.
. "What's Be Happen? A Bakhtinian Analysis of Aotearoa New Zealand's First Pacific Reggae Album." Auckland University of Technology, 2016.

Walker, Ranginui. Ke Whawhai Tonu Matou: Struggle without End 2nd ed. Auckland, New Zealand: Penguin, 2004.

Waring, Marilyn. "A Feminist Perspective." In Glory Days: From Gumboots to Platforms, edited by lan Chapman, 155-58. Auckland, New Zealand: HarperCollins, 2009

Weber, Thomas, J. "Likkle but Talawah (Small bu Mighty): Reggae Music, Globalization, and the Birth of a Social Movement (Phd Thesis)." Bowling Green State University, 2000.

(Aldershot: Ashgate Publishing, 2007), p.2.

5 Gerard Genette, Paratexts: Thresholds of Interpretation (Cambridge, England: Cambridge University Press, 1997). Peritext is one of two general categories identified by Genette in his theorisation of the practices and discourses constituting supplementary paratext, which is next to but beyond the main text of a book, and yet constituent of it. Peritext includes cover images, titles and contents pages, for example, which "surround" and are materialy adjacent to surround" and are materially adjacent to the primary text, they extend it, but have no meaning except in relation to that tex Epitext includes promotional material and newspaper reviews, for example, that are not necessarily materially attached to the primary text but circulate in relation to it. Genette suggested that the idea of paratextuality could be extended from books to musical recordings, where the text itself is the vinyl record or $\mathrm{CD}$ and the sleeve or other "containment devices" are the paratext (Colin Symes, Setting the Record Straight: A Materia History of Classical Recording (Middletown, CT: Wesleyan University Press, 2004), 95.). Colin Symes' response to Genette's suggestion employs the notion of paratext in the study of materials that surround classical long playing records (LPs), conceptualising record covers as important textual extensions of the records themselves, and extending Genette's analysis of the narrative architecture of books to this different cultural form. Paratext is seen as a threshold to the texts they refer to (Genette, Paratexts: Thresholds of Interpretation.) and elements of peritext and epitext act as "thresholding devices" (Symes, Setting the Record Straight: A Material History of Classical Recording, 95.) which convey information and can signal authorial intentions; they "present" the text and help to frame readers' approaches to it.

6 The examination of the paratext of Herbs' album cover is informed by David Machin's analysis of the text and iconography (the mages and symbols) of popular music album covers. (See David Machin, Analysing Popular Music: Image, Sound, Text (London, England: Sage, 2010).) In multimodal examinations of the ways in which record sleeves communicate identities and values and signify particular discourses, Machin builds on the semiotic theory and approaches of Roland Barthes (Roland Barthes, Image/ Music/Text, trans. S. Heath (New York, NY: Noonday, 1977).) and of Gunther Cress and Theo van Leeuwen (Gunther R. Kress and Theo van Leeuwen, Reading Images:The Grammar of Visual Design (London, England: Routled 1996). Relevint visual language features discussed by Machin in discussed by Machin include images and wh these may document and denote, as well as the values and concepts they may connote; that is their "meaning potential" (Machin Analysing Popular Music: Image, Sound, Text, 37.) As others have pointed out, such connotations are historical and social, being dependent on the conventions, expectations and cultural values of the society in which an image appears and is interpreted (See for example, Mikhail Bakhtin, "Toward a Methodology for the Human Sciences," in Speech Genres and Other Late Essays ed. Caryl Emerson and Michael Holquist (Austin, TX: University of Texas Press, 1986).; and Barthes, Image/Music/Text). Machin also identifies the relevance of techniques that signify salience, visual modality, and the semiotic resources of colour and typography. Salience is the degree of importance of visu elements as carriers of meaning; this may be signified by the inclusion of culturally significant symbols, by foregrounding elements, and as Cal Swann also points out through relative size (Cal Swann, Language \& Typography (London, England: Lund Humphries, 1991). The modality of images Humphries, 1991). The modality of images
refers broadly to the degree to which an image expresses certainty and is "real, more real or less than real" (Machin, Analysing Popular Music: Image, Sound, Text, 10.), that is the extent to which it is perceived as expressing truthfulness and certainty, as an image of "realness" (Barthes, Image/Music/ Text.).

7 Mikhail Bakhtin, Problems of Dostoevsky's Poetics, trans. Caryl Emerson (Manchester, England: Manchester University Press, 1984), p.197.

8 See Michael King, The Penguin History of $\mathrm{New}$ Zealand (Auckland, New Zealand: Penguin 2003).

9 Toni Fonoti, What's Be Happen? [Recorded by Herbs]. On What's Be Happen? [Vinyl Record], (Auckland: Warrior Records/WEA, 1981d).

10 Toni Fonoti, personal communication October 5, 2012

11 Al Cleveland, Renaldo Benson, and Marvin Gaye. What's Going on [Recorded by Marvin Gaye]. On What's Going on [Vinyl Record]. Detroit, MI: Tamla Records, 1971.

12 Phil Toms interview with the author,

Auckland, November 21, 2013.

13 See historian Jock Phillips, cited in Anthony Hubbard, "For a Good Cause," Sunday Star Times, August 292010.

14 King, The Penguin History of New Zealand Marilyn Waring, "A Feminist Perspective," in Glory Days: From Gumboots to Platforms, ed. Ian Chapman (Auckland, New Zealand: HarperCollins, 2009); King, The Penguin History of New Zealand.

15 See Elizabeth Turner, "What's Be Happen? A Bakhtinian Analysis of Aotearoa New Zealand's First Pacific Reggae Album" (Auckland University of Technology, 2016).

16 "One Brotherhood in Aotearoa New Zealand: Protest, Resistance and Pacific Reggae," Music and Politics XII, no. 2, Summer 2018.

17 See Michael Dunn, New Zealand Sculpture: A History (Auckland, New Zealand: Auckland University Press, 2002).

18 lbid. 
19 Phil Toms, One Brotherhood [Recorded by Herbs]. On What's Be Happen? [Vinyl Record] Auckland, New Zealand: Warrior Records, 1981).

20 See Ranginui Walker, Ke Whawhai Tonu Matou: Struggle without End 2nd ed.

(Auckland, New Zealand: Penguin, 2004).

21 Bruce Morrison, "Bastion Point: The Untold Story (Tv Documentary)," (New Zealand: Morrison Grieve and Moko Productions, 1999 ).

22 See Peter Morton Hoar, "Hearing the World: Audio Technologies and Listening in New Zealand, 1879-1939" (The University of Auckland, 2012).

23 Terry Eagleton, How to Read a Poem (Oxford, England: Blackwell, 2007), 31

24 Ross France, Azania [Recor What's Be Happen? [Vinyl Record]. (Auckland, New Zealand: Warrior Records, 1981).

25 See Walker, Ke Whawhai Tonu Matou: Struggle without End

26 Toni Fonoti, Dragons and Demons [Recorded by Herbs]. On What's Be Happen? [Vinyl Record]. (Auckland, New Zealand: Warrio Records, 1981c).
27 Reggae's Doing Fine [Recorded by Herbs]. On What's Be Happen? [Vinyl Record]. (Auckland, New Zealand: Warrior Records/WEA, 1981b).

28 Whistling in the Dark [Recorded by Herbs]. On What's Be Happen? [Vinyl Record]. (Auckland, New Zealand: Warrior Records/WEA, 1981a).

29 Thomas Weber, J., "Likkle but Talawah (Small but Mighty): Reggae Music, Globalization, and the Birth of a Social Movement (Phd Thesis)" (Bowling Green State University, 2000), 121.

30 See Stuart Hall, "Cultural Identity and Diaspora," in Identity: Community, Culture, Difference, ed. J. Rutherford (London, England: Lawrence and Wishart, 1990).

31 Walker, Ke Whawhai Tonu Matou: Struggle

$$
\text { without End }
$$

32 James Belich, Paradise Reforged (Auckland, New Zealand: Penguin, 2001), 475 